\title{
Enhancing the Entrepreneurial and Intrapreneurial Attributes of Engineering Graduates: A Review Proposal for Metallurgy and Materials Engineering Undergraduate Curricula at Two African Universities
}

\author{
Elias Matinde $(\mathbb{D}$ \\ School of Chemical and Metallurgical Engineering, University of Witwatersrand, Johannesburg 2050, \\ South Africa; ematinde263@gmail.com
}

Received: 15 November 2018; Accepted: 21 December 2018; Published: 27 December 2018

\begin{abstract}
This paper explores the potential opportunities to enhance the entrepreneurial and intrapreneurial attributes of graduates in the Metallurgy and Materials Engineering curricula at two universities in Zimbabwe and South Africa. Due to the diminishing geographical constraints between Zimbabwe and South Africa, and the strong juxtaposition between the two economies, this paper adopts a simplified comparative education methodology to benchmark education best practices between these two countries. While the reviewed curricula in their present form may be providing learners with opportunities for disciplinary problem solving and inquiry-based learning, this paper proposes a body-centred cubic (bcc) model to integrate a new dimension of entrepreneurial and intrapreneurial education into the teaching and learning space. Based on the 3D bcc lattice with six planes, where the first five planes represent the current curricula, pedagogy practices and desired attributes, the sixth plane is taken to represent the additional dimensions of the desired entrepreneurial and intrapreneurial attributes.
\end{abstract}

Keywords: multi-disciplinary knowledge; enquiry-based learning; comparative education; body centred cubic model

\section{Introduction}

Curriculum in the higher education space has always been a highly contested field, particularly on issues such as (1) what problems curriculum in higher education should be addressing, (2) how the curriculum should be structured in the teaching and learning context, and (3) how it should address the societal needs and diverging desires of the various stakeholders involved [1]. Cornbleth [1] highlighted the importance of our conceptions on curriculum and the process of curriculum making, and how the ways of reasoning about curriculum reflect and shape how we see, think and talk about, study and act on the education made available to our students. In addition to this, extensive research in curriculum construction has highlighted the agentic challenges in curriculum construction exerted by the global, national, institutional, and societal interests on the learners' epistemological and ontological development [2-4]. Due to the diverging views and interests on curriculum and its construction, it is thus important to take into account, and balance, the conflicting demands exerted by the key stakeholders, especially on how such dichotomous demands would potentially impact the desired attributes and virtues of the university graduates.

Extensive research on curriculum in higher education is cognizant of how curriculum making is a delicately negotiated process encompassing the socio-economic and pedagogic demands of the discipline and subject area in order to accentuate the desired attributes, virtues and dispositions within the higher education space [3-10]. Based on the South African context, Luckett [3] highlighted 
the critical role of curriculum in the social and economic transformation, particularly on the role of public universities as catalysts for socio-economic transformation. According to Luckett [3], a good curriculum should produce graduates with requisite skills to help transform the economy into a competitive global economy. The somewhat divergent views on curriculum, and the complex roles of institutions of higher learning, thus create turbulence and opportunities as well on the desired virtues and dispositions of university graduates.

In recent years, curriculum construction in engineering sciences, and its impact on the attributes of engineering graduates thereof, has attracted considerable attention from various stakeholders. This paper integrates the various arguments on engineering curriculum and provides a comprehensive review on the generic, and emerging, attributes of engineering graduates. Based on the theoretical perspectives on innovation, entrepreneurial and intrapreneurial attributes, the paper challenges the adequacy of a traditional disciplinary-focused curriculum. This paper adopts a simplified comparative education approach to assess the differences and/or similarities of the curricula at two African universities, and proposes a body centred cubic $(\mathrm{bcc})$ model for the integration of entrepreneurial and intrapreneurial skills in engineering education.

\section{Graduate Attributes}

A curriculum is intended to create conditions of possibility for a trajectory of learning and should fundamentally act as a pathway for life-long learning by repositioning the learners' epistemic and ontological perspectives in a disciplinary subject [11]. Thus, an effective curriculum should not only equip the learners with the requisite disciplinary knowledge but also develop learners' disciplinary identity as well as inducting them into the professional community of practice $[12,13]$. However, due to dramatic and fluxing changes in the global economic environment, the notion of an ideal university graduate is constantly being challenged, particularly in terms of interdisciplinary knowledge, critical thinking, and life-long learning capabilities.

The complexity in the current global economy has precipitated turbulence on how curriculum content and construction in higher education institutions should be. Technically, the ubiquitous and fluid nature of the global economy translates to ever-increasing pressure and expectations on higher learning institutions to produce highly knowledgeable and yet adaptive graduates [5-7]. The demand on the ubiquity of skills in the global space means that disciplinary knowledge alone is no longer sufficient; hence, there is a need to develop a more agile curriculum that equips graduates with the core disciplinary knowledge as well as interdisciplinary skills such as critical thinking and emotional intelligence [5]. In this context, emotional intelligence is defined as the capability of graduates to deploy trans-disciplinary knowledge by integrating the core-disciplinary knowledge with soft skills such as self-reflexivity, creativity and serendipity, resilience, teamwork and systems thinking $[5,14,15]$. The balance is particularly important under the current constrained socio-economic conditions currently being experienced by most countries in the global south.

\subsection{Innovation, Entrepreneurial and Intrapreneuerial Attributes}

Extensive research in social and business sciences has been dedicated to demystifying the interacting forces driving the technological innovation, entrepreneurial and intrapreneurial tendencies of individuals and organizations [16,17]. Fundamentally, pioneering literature in business and economic sciences defines technological innovation as: (1) the introduction of new products, new methods of production, (2) developing and opening up new markets, (3) developing new sources of supplies of raw materials or other inputs, and (4) the creation of new market structures or new forms of organizations in an industry of new products $[16,17]$. Over the years, there has been a growing consensus on the importance of entrepreneurs and intrapreneurs in driving economic growth. Through incremental and/or disruptive innovations, entrepreneurs and intrapreneurs constantly create new market structures and shape the competitive landscape in an industry sector [16-25]. 
Fundamentally, there are slight, but somewhat converging, differences between entrepreneurs and intrapreneurs. The term entrepreneur commonly refers to individuals who organize, manage, and assume the risks of a new business or enterprise $[16,17,26]$. On the other hand, intrapreneurs are individuals operating within an organization or company who take risks in an effort to solve business problems [27]. Based on classical and neoclassical economic theories, Wennekers and Thurik [20] explicitly defined entrepreneurs as individuals or teams, operating within and outside existing organizations, who undertake to create new economic opportunities and introduce their ideas into the market under conditions of uncertainty and other obstacles. Furthermore, Wennekers and Thurik [20] and Dejardin [21] categorized entrepreneurs into four different groups: (1) Schumpeterian entrepreneurs (entrepreneurial and self-employed), (2) intrapreneurs (entrepreneurial and employee), and (3) managerial business owners (managerial and self-employed) and (4) executive managers (managerial and employee). Since entrepreneurs and intrapreneurs actively contribute to the market creative destruction processes, their skills sets are thus indispensable in driving economic growth and the competitiveness of the industries in which they are embedded [16-24]. In fact, extensive literature in business and economic sciences supports the proposition that the entrepreneurship and innovation are attributes not only confined to individuals and small firms. For example, these attributes are also responsible for driving the competitiveness of existing corporations in the form of new ideas, new business units, strategic renewal, and organic research and development programs [18-20].

Based on the aforementioned arguments, there have been intense debates on the role of appropriate education as an exogenous catalyst for innovation, entrepreneurship and intrapreneurship [28-31]. Although currently there are no quintessential attributes of entrepreneurship education and/or components of it within the mainstream education space, Kuratko [28] argued that entrepreneurship, or certain facets of it, can be taught and/or at least encouraged by entrepreneurship education. Laukkanen [29] proposed a model for university-based entrepreneurial education as a regional evolution mechanism and business generating model aimed at fostering conditions for new ventures, and catalyzing the emergency of viable business concepts and entrepreneurial actors, resources and munificent environments. Baumol [23] highlighted that education can act as an enabler of innovation by providing the mastery of invaluable scientific knowledge and methods to future entrepreneurs and intrapreneurs which can stimulate creativity and imagination. Nonetheless, Baumol [23] also reiterated that education that is not properly packaged and aligned can also act as a hindrance by impeding heterodox thinking and imagination. Based on the US ABET system, Nichols and Armstrong [26] proposed a pedagogical justification for including in engineering curricula courses and materials in engineering entrepreneurship as a strategy to provide a framework for addressing engineering problems in a societal context. In recent studies, Oswald-Beiler [31] proposed infusing the principles of entrepreneurship education in undergraduate engineering programs in order for the learners to integrate engineering knowledge with management processes, ethics, leadership, communication skills, and open-ended problem-solving capabilities.

\subsection{Case for Engineering Sciences}

As opposed to the widely documented research on curricula construction in social sciences over the years, debates on the construction of curriculum in engineering sciences have been few and far between [4,10,32-35]. In fact, curriculum debate in engineering education has been largely dominated by what professional engineering bodies and the engineering fraternity think is important based on workplace-related technical skills and ability to solve real-world problems [10]. Maton [34] proposed that engineering education is located at the heteronomous pole of higher education where external influences from key stakeholders, such as professional bodies, regulatory bodies and industry, play a significant role in determining what gets valued. As a result, the interactive agentic factors of stakeholder and regulatory agencies in engineering education may present challenges to the implementation of a holistic and agile curriculum. In South Africa, for example, the Engineering Council of South Africa [36] oversees the quality of the engineering curriculum on behalf of the state 
and the engineering fraternities through regular audits based on prescribed learning outcomes. Such a technocratic conception considers curriculum as a document highlighting the learning outcomes, the assessment practices, and the content to be covered. However, this narrow and prescribed view of the desired set of attributes may not fully take into account the emerging needs of the profession as well as the dynamic nature of the engineering practice [1-4].

The ability of engineering graduates to solve workplace-related and real-world problems has been, and is still, the central focus of curriculum debates globally. Other studies have also expanded on these generic technical and problem-solving attributes to include more focus on, among other things: (1) practical application, theoretical understanding, creativity and innovation [37], (2) the engineering life cycle, with increasing emphasis on dealing with uncertainty and risk assessment, systems thinking, and integrating ideas and technologies [38], (3) systems thinking and engineering design [39], (4) integrating information and communication technologies into engineering practice [12], and (5) global competencies and understanding the nature of engineering practice, including awareness of geopolitical and societal issues, cross and multicultural issues as well as international labor market and workplace imperatives $[9,40]$. Sunthonkanokpong [40] further highlighted the desired competencies of future global engineers to include: (1) technically adept, broadly knowledgeable, lifelong learner and culturally aware, (2) entrepreneurial spirit, innovative and understanding of world markets, (3) ability to translate technological innovation into commercially viable products and services, and (4) professionally nimble, flexible, and mobile. Despite the various authors presenting diverging views of engineering curriculum construction and pedagogy, it is clear that a holistic engineering curriculum should aim to produce multi- and trans-disciplinary graduates who are capable of solving complex societal and business problems under conditions of uncertainty [8-10,30,39,41-46]. Thus, the various arguments presented by the researchers provide opportunities for debate and continuous improvement in the deployment of agile and futuristic curricula in engineering education.

The arguments raised so far clearly highlight the need to change the mandates of institutions of higher learning from a disciplinary knowledge driven curriculum, to the integration of such disciplinary knowledge with the previously overlooked domains of innovation, entrepreneurship and intrapreneurship [6]. Although these attributes are usually inherent in individuals and cannot easily be taught, it is equally important to explore ways of enhancing such skills through an integrative engineering curriculum. It is therefore clear that the conflation towards integrating the attributes of entrepreneurial intent into the teaching and learning of engineering sciences is a potential panacea for addressing the employability and self-sustenance of university graduates.

\section{Methodology}

Comparative education involves the analysis of educational similarities and differences between regions of the world, or between two or more jurisdictions, and considers best practices in education from a global and/or regional perspective [47]. It is basically defined as a field of study dealing with the comparison of current educational theory and practice in different countries for purposes of broadening the understanding of education practices beyond the boundaries of one's own country [48]. In detail, comparative education methodologies use data, systems and design policies to examine education systems. Focal to comparative education is the content analyses of curriculum and its intention in meeting the short- and long-term institutional and national objectives of developing robust graduate competencies [49].

Due to the diminishing geographical constraints between Zimbabwe and South Africa, and the strong juxtaposition between the two economies, comparative education provides opportunities to benchmark the education best practices between these two countries. Furthermore, from an alumnus' point of view, the University of Zimbabwe would stand to benefit from benchmarking their curriculum with that of the higher ranked University of Witwatersrand. The present study adopts a simplified comparative education approach based on qualitative content analyses of the existing curricula, to evaluate the two curricula at two national universities in Zimbabwe and South Africa. The objective 
of this paper is to comparatively evaluate opportunities to integrate entrepreneurship education into the current Metallurgy and Materials Engineering undergraduate curricula at the University of Zimbabwe and the University of Witwatersrand. Although in principle, the key stakeholders seem to be fundamentally satisfied with the current curricula in these jurisdictions, there are plenty of opportunities for continuous improvement. This paper further explores the opportunities for curriculum review towards enhancing the entrepreneurial and intrapreneurial attributes of engineering graduates under the current constrained economic environments being experienced in both countries. The arguments articulated in this paper are based on the author's experience as an alumnus of the University of Zimbabwe BSc (Hons) Metallurgy and Materials engineering program (1999-2002) and as current lecturer in the BSc (Hons) Metallurgy and Materials engineering program at the University of Witwatersrand. In order to fully grasp the arguments proposed in this paper, it is important to evaluate the context and the economic environments in Zimbabwe and South Africa.

\section{Contextual Background to the Study}

The economic fundamentals in these two countries are largely driven by natural resources, with the mining industry contributing a significant portion to the gross domestic product (GDP) [50-53]. In other words, the competitiveness of these two countries is largely driven by the exploitation of natural resources rather than on efficiency and differentiated products. In the recent years, both countries have prioritized the beneficiation of their natural resource endowments and in building advanced manufacturing capabilities in an effort to transform the existing comparative advantage into sustainable competitive advantages [50-53]. In this context, value added manufacturing refers to the core steps in the production process that result in improved product value and high net worth and is predicated on a structured framework that captures the competitiveness of the advanced manufacturing activities along the various value chains [53]. As such, there is need to complement the ambitious beneficiation framework with value added manufacturing capabilities driven by the entrepreneurial spirit of the citizens $[53,54]$. The aforementioned ambitions dictate the need to develop a robust human capital base in the form of high-level transferable, entrepreneurial, and intrapreneurial skills to drive value innovation within the respective industry sectors.

\subsection{University of Zimbabwe (UZ)}

The University of Zimbabwe is located in the leafy suburb of Mount Pleasant in Harare and offers a four-year BSc (Hons) degree in Metallurgical Engineering. The program covers the core disciplinary courses in Extractive Metallurgy and Materials Engineering as well as transdisciplinary and complementary courses such as Natural Sciences (Mathematics, Mechanics and Chemistry), Geology, Communication Skills, Computing Science, Engineering Drawing and Design, Professional and Industrial Studies, and Environmental Engineering. The program has both cornerstone and capstone research project components for the third and fourth year of study, as well as a compulsory eighteen-week industrial placement during academic semester breaks. The undergraduate degree program is accredited by the Engineering Council of Zimbabwe, but there are no publicly available standardized criteria governing the expected learning outcomes.

\subsection{University of Witwatersrand (Wits)}

The University of Witwatersrand is located in central Johannesburg and offers a four year BEng (Hons) degree in Metallurgy and Materials Engineering. The program covers the core disciplinary courses in extractive metallurgy and materials engineering as well as transdisciplinary and complementary courses such as Natural Sciences (Mathematics, Physics, and Chemistry), Mineralogy and Earth Sciences, Critical Thinking Skills, Psychology (Human Performance and Organization Behavior), Computing Science, Management Fundamentals, and Environmental Engineering. In addition to the final-year research project, the program also incorporates cornerstone and capstone metallurgical design components. Learners are also expected to undergo compulsory 
industrial placements during academic semester breaks. The undergraduate degree program at Wits is accredited by the Engineering Council of South Africa based on prescribed expected learning outcomes. Table 1 shows a comparative evaluation of the core and complementary courses in the two universities.

Table 1. Comparative evaluation of some of the core and multi-disciplinary curricula at the two institutions (Extracted from reference [36]).

\begin{tabular}{|c|c|c|c|}
\hline Course & Learning Outcomes & $\mathrm{UZ}$ & Wits \\
\hline $\begin{array}{l}\text { Core disciplinary courses (Extractive } \\
\text { Metallurgy, Physical Metallurgy, } \\
\text { Advanced Materials Engineering) }\end{array}$ & $\begin{array}{l}\text { Problem solving; identify, assess, formulate, and solve } \\
\text { convergent and divergent engineering problems creatively } \\
\text { and innovatively. }\end{array}$ & $\sqrt{ }$ & $\sqrt{ }$ \\
\hline Practical laboratory components & $\begin{array}{l}\text { Investigations, experiments, and data analysis; professional } \\
\text { and technical communication. }\end{array}$ & $\sqrt{ }$ & $\sqrt{ }$ \\
\hline $\begin{array}{l}\text { Natural Sciences (Mathematics, Physics, } \\
\text { Chemistry, Mechanics) }\end{array}$ & $\begin{array}{l}\text { Application of scientific and engineering knowledge; problem } \\
\text { solving; quantitative reasoning and explaining natural and } \\
\text { engineering phenomena. }\end{array}$ & $\sqrt{ }$ & $\sqrt{ }$ \\
\hline Engineering design & $\begin{array}{l}\text { Creative, procedural and non-procedural design and synthesis } \\
\text { of components, systems, engineering works, products } \\
\text { and processes. }\end{array}$ & $\sqrt{ }$ & $\sqrt{ }$ \\
\hline Environmental engineering & $\begin{array}{l}\text { Impact of engineering activity; critical awareness of the } \\
\text { impact of engineering activity on the social, industrial and } \\
\text { physical environment. }\end{array}$ & $\sqrt{ }$ & $\sqrt{ }$ \\
\hline $\begin{array}{l}\text { Complementary sciences } \\
\text { (Communication Skills/Critical thinking) }\end{array}$ & $\begin{array}{l}\text { Technical communication; critical thinking; social awareness; } \\
\text { multi-disciplinary problem solving. }\end{array}$ & $\sqrt{ }$ & $\sqrt{ }$ \\
\hline Management and industrial studies & $\begin{array}{l}\text { Engineering professionalism; engineering management } \\
\text { principles; economic decision-making; management and } \\
\text { leadership; ethics; operations research. }\end{array}$ & $\sqrt{ }$ & $\sqrt{ }$ \\
\hline Capstone research project & $\begin{array}{l}\text { Independent learning ability; application of scientific and } \\
\text { engineering knowledge; problem solving based on } \\
\text { open-ended scientific and engineering problems. }\end{array}$ & $\sqrt{ }$ & $\sqrt{ }$ \\
\hline Cornerstone design project & \multirow{2}{*}{$\begin{array}{l}\text { Engineering methods, skills, and tools, including information } \\
\text { technology; problem solving-open ended scientific and } \\
\text { industrial problems; design systems, processes and/or } \\
\text { components to solve complex/open-ended engineering } \\
\text { problems. Validates designs against problem specifications. }\end{array}$} & $\sqrt{ }$ & $\sqrt{ }$ \\
\hline Capstone design project & & $x$ & $\sqrt{ }$ \\
\hline
\end{tabular}

\section{Analysis and Discussion}

As shown in Table 1, there are strong similarities in the core and specialization curricula between the two universities. Basically, the broad objectives of the two curricula are to equip the learners with the requisite technical skills and capabilities to solve complex engineering problems. Because engineering sciences are traditionally described as a region located at the interface between the field of production and field of practice [32], the two curricula are designed to induct graduate engineers into professional engineering practice based on solid grounding in mathematics, natural sciences, engineering concepts and engineering design. In addition, the two curricula tend to focus on attaining minimum competencies based on the hybrid variants of problem-based learning (PBL) and cognitive threshold concepts which are essential for developing life-long capabilities among the graduates. The combination of these core and threshold concepts in the core curricula are further integrated with complementary courses such as Professional and Industrial Studies (for UZ), Communication Skills and Critical Thinking (UZ and Wits), Computing Sciences (UZ and Wits), Management Fundamentals (Wits), Psychology of Human Performance and Organization Behavior (Wits), cornerstone research component (UZ), capstone research project (UZ and Wits), cornerstone design project (UZ and Wits) and capstone design project (Wits). In other words, the current curricula were designed to integrate both disciplinary and interdisciplinary learning by linking the core engineering concepts to interdisciplinary knowledge as well as some tenets of engineering practice through compulsory industrial placements during semester breaks. Essentially, the interdisciplinarity process requires synthesis of various disciplinary knowledges and methods to provide a more holistic 
understanding of a given problem $[15,55-57]$ and is crucial in engineering education in order to develop interdisciplinary thinking and problem solving in engineering practice.

\subsection{Inquiry-Based and Research-Based Teaching}

Due to constrained socio-economic conditions in Zimbabwe over the past decade, the University of Zimbabwe has lost experienced research academics who could actively take part in both teaching and academic research. Conversely, the University of Witwatersrand has a strong team of research-intensive academics in the Metallurgy and Materials Engineering discipline. To date, Wits hosts professorial chairs in Hard Materials, Ceramics, Clean Coal Technology, Extractive Metallurgy, and Hydrometallurgy. Although the focus of undergraduate programs is not on training academics and scientists, there is growing interest in most academic jurisdictions in consolidating the research and teaching activities as a way of cultivating scholarship, problem-based, experiential, and inquiry-based learning at a grassroots level [58].

As highlighted in Table 1, the capstone research projects form a critical component of both curricula. These components are solely designed to infuse independent learning abilities by enabling the learners to work independently and reflectively in synthesizing scientific literature, design and execute their own experiments, and interpret their own data to make suitable and reasonable conclusions [36]. Basically, the learners' competencies in the research components are assessed based on the delivery of a coherent research report and/or publishable journal article, and on the ability to communicate their research findings in the form of an oral and poster presentation.

Although the link between quality of teaching and learning and research in the university is contested, Healey $[59,60]$ argued that research impacts the quality of teaching in a way that courses taught by those at the cutting edge of research tend to be of higher quality than those taught using research results of others. Research naturally promotes tolerance of ambiguity and uncertainty and involves questioning of one's own knowledge and understanding [61]. As a result, research-based teaching is considered an effective way of developing questioning and inquiring mind-sets among learners [61]. Furthermore, Healey $[59,60]$ noted that research-based teaching allows students to learn more about research methods and techniques, learn by undertaking their own projects and/or by gaining experience of applied research and consultancy through work-based learning. The views by Healey $[59,60]$ are also reinforced by Kolb's experiential learning model, which in essence considers learning and knowledge creation as continuous processes wherein new knowledge is continuously being derived from and tested out in the experience of the learner through processes [62]. Therefore, comparatively, the curriculum at Wits is better positioned to equip the learners with inquiry-based learning due to the stronger research inclination of the teaching staff.

\subsection{Cornerstone and Capstone Design Projects}

In addition to cornerstone design projects which are embedded in the core disciplinary courses in both programs in the earlier years of engineering education, Wits has a separate but integrated capstone design project. Since most engineering design projects are conceptualized based on imperfect models, incomplete information, and ambiguous objectives [39,63], the broad objective of this capstone design project is to develop systematic cognitive and problem-solving skills, as well as conceptual reasoning and critical thinking skills among the learners. The learners are usually given an open-ended engineering problem and are then expected to demonstrate competence to perform creative, procedural and non-procedural design and synthesis of components, systems, engineering works, products or processes, and the assessment of competencies are then tailored to the problem that is to be solved [36]. Depending on the nature of the design task, the learners are evaluated on the ability to apply fundamental scientific and engineering knowledge to solving open-ended scientific and engineering problems as well as the integration of design thinking to solve complex and/or open-ended engineering problems and validating such designs against problem specifications [36]. For example, a design task involving process flowsheet development would be assessed based on aspects such as 
the coherence and reasonableness of the flowsheet, equipment selection and specification, selection of materials of construction, specification of products and product streams, economic evaluation of the designs based on tenets of project management, and the safety, health and environmental aspects.

In general, the major responsibility of professional engineering practice is to create solutions and design systems that meet social, industrial, and commercial needs [45]. The pedagogic efficacy in developing design skills among engineering graduates in meeting such needs, particularly in the form of design and systems thinking and/or its variants thereof, has been a subject for debate for years [39,41-43,63-66]. Grounded on systems thinking processes of solving complex problems, Dym [41,42] and Dym et al. [39] defined engineering design as a thoughtful process that depends on the systematic and intelligent generation of design concepts and specifications. These researchers further defined design thinking as reflecting the complex processes of enquiry and learning that designers perform in a systems context and making decisions as they proceed.

Well-structured design tasks require learners to think holistically [66], and as such, several researchers have emphasized the need to integrate systems thinking into engineering design pedagogies, as such an exposure to a non-deterministic design environment can help the learners to deal with uncertainty $[39,41-43,63]$. In particular, Sterman [43] defined systems thinking as the ability to see the world as a complex and interconnected system. This approach involves taking into account the reflexive interconnectedness among the variables based on the supposition that it is possible to explain the whole by analysing the constituent parts in isolation [43,63]. In fact, this proposition has since been adopted to form the guiding principles of the underlying pedagogies in project- and design-based engineering education $[43,63]$. The success of the design projects in the two curricula is thus predicated on the alignment of the systems thinking and design to the task requirements, as well as the assessment and validation processes and practices employed by the facilitators.

\section{Integrating Entrepreneurship Education in Engineering Curriculum}

\subsection{Body-Centred Cubic Model}

This section proposes the conceptualization of the entrepreneurial and intrapreneurial enhanced curriculum based on a conceptual bcc lattice model commonly used in analyzing metallic crystal structures in Metallurgy and Material Sciences [67,68]. Simplistically, the bcc is a 3D crystal lattice structure with one atom on each of the corners and one in the centre of the cube $[67,68]$. Iron, chromium and tungsten are some of the most important metals known to mankind that exhibit a bcc structure at room temperature $[67,68]$. The proposed model considers a bcc lattice (shown in Figure 1) with six planes $A B C D, A B E G, E G H F, A C E F, C D H F$ and BDGH. In this case, the first five planes $A B C D$, $\mathrm{ABEG}, \mathrm{EGHF}, \mathrm{ACEF}$ and $\mathrm{CDHF}$ represent the tenets of the current undergraduate curricula. The sixth plane (BDGH) then represents the additional dimensions that incorporate the new desired attributes (shown in Table 2). Technically, the proposed curriculum reform and pedagogical practices proposed in this paper are based on interlinking the sixth plane to the current curricula. The proposed desired entrepreneurial and intrapreneurial attributes are then represented by the atom at the centre of the cubic lattice.

As shown in Figure 1, the desired graduate attributes are represented by the atom at the centre of the lattice by integrating the knowledge components represented in the six planes. Career-wise, Metallurgy and Materials Engineering graduates tend to pursue diverse career paths along the minerals, metals and energy resources value chains, and in financial, research and consulting sectors as well $[66,69]$. Due to the diversity of career pathways, it is thus desirable to integrate into the current curricula the proposed aspects of entrepreneurship education represented by plane BDGH. Table 3 highlights some of the benefits of integrating entrepreneurial and intrapreneurial education in engineering sciences $[6,8,9,12,13,31,37,41-46,63,70-72]$. 


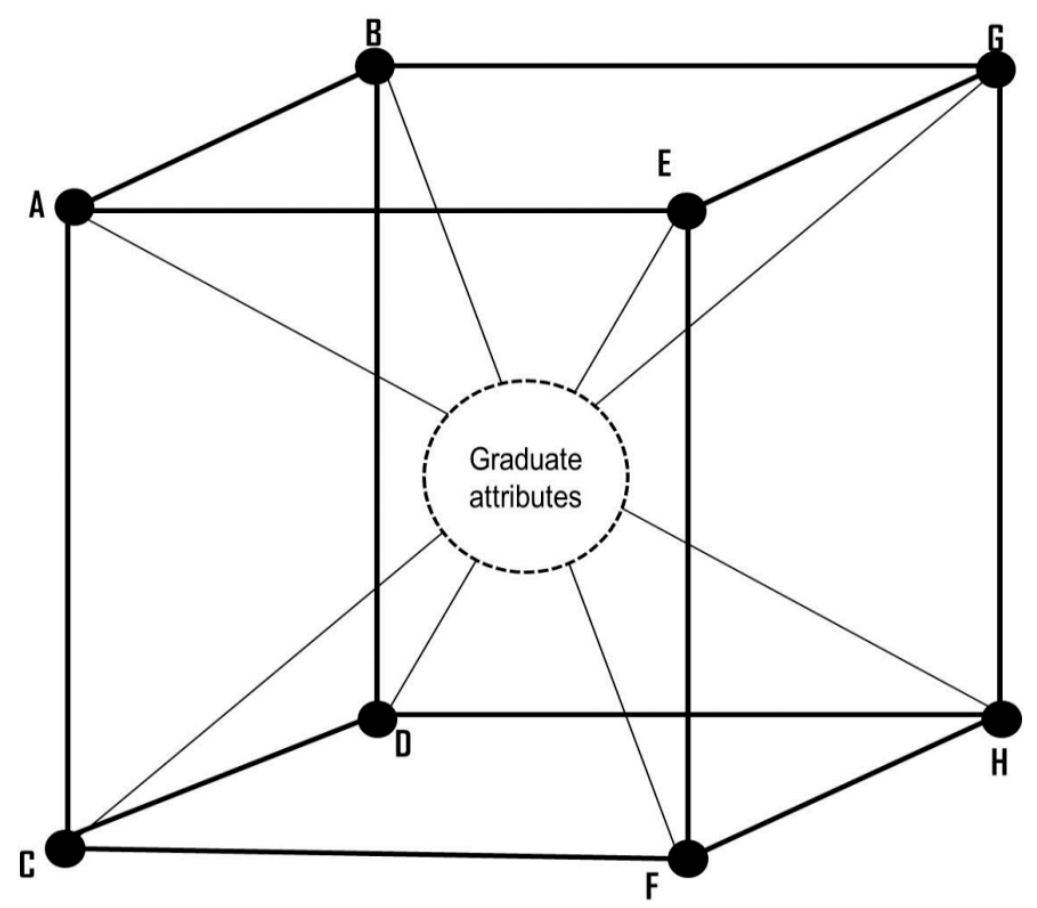

Figure 1. Proposed body-centred cubic (bcc) model for achieving desired graduate attributes.

Table 2. Proposed graduate attributes based on the bcc model.

\begin{tabular}{|c|c|c|c|}
\hline & Plane & Knowledge Domains & Desired Outcomes and Competencies \\
\hline 1 & $\mathrm{ABCD}$ & $\begin{array}{l}\text { Core disciplinary } \\
\text { knowledge }\end{array}$ & \multirow{2}{*}{$\begin{array}{l}\text { Solve complex engineering problems; integration into professional } \\
\text { engineering practice based on solid grounding in mathematics, natural } \\
\text { sciences engineering sciences and design. }\end{array}$} \\
\hline 2 & ABEG & Natural sciences & \\
\hline 3 & EGHF & Complementary studies & $\begin{array}{l}\text { Interdisciplinary and multidisciplinary thinking and problem solving } \\
\text { in engineering; critical thinking and analysis. }\end{array}$ \\
\hline 4 & $\mathrm{ACEF}$ & Capstone research & $\begin{array}{l}\text { Problem solving and communication; independent and reflective } \\
\text { learning abilities; systems thinking for experimentation and empirical } \\
\text { data collection; self-awareness and reflection on the scientific, } \\
\text { industrial, economic and environmental impacts of own research. }\end{array}$ \\
\hline 5 & $\mathrm{CDHF}$ & Engineering design & $\begin{array}{l}\text { Systems thinking and problem solving: Designing systems, processes } \\
\text { and/or components to solve complex/open-ended engineering } \\
\text { problems and validating them against problem specifications. }\end{array}$ \\
\hline 6 & BDGH & $\begin{array}{l}\text { Entrepreneurship, } \\
\text { intrapreneurship and } \\
\text { design thinking }\end{array}$ & $\begin{array}{l}\text { Creative problem solving; economic, financial and market analysis; } \\
\text { business case and business plan development; market analysis and } \\
\text { opportunity recognition; business portfolio and value proposition; } \\
\text { problem solving and reflexivity to provide simple solutions to complex } \\
\text { societal and business problems. }\end{array}$ \\
\hline
\end{tabular}

The proposed benefits highlighted by plane BDGH and Table 3 also resonate with propositions by several other researchers [26,30,31,46,63,70-72]. Nichols and Armstrong [26] proposed a concept of "from the lab to the market" as an organized approach to entrepreneurship by relating the market needs to the ongoing university research activities. The concept enables the learners to work in interdisciplinary teams in developing various approaches to commercialization of specific technologies. Based on a study in South African universities of technology, Odora [71] proposed integrating product design and entrepreneurship education as an entrepreneurial stimulant for enterprising design and engineering learners. Kriewall and Mekemson [70] proposed a pyramid model of an entrepreneurial engineer based on technical fundamentals, business acumen, customer awareness and societal values attributes of the engineering graduates. Furthermore, Liebenberg and Mathews [63] proposed integrating the multi-faceted design-build-innovate module into the undergraduate engineering curriculum to inculcate creative problem-solving abilities for technological 
problems. The assessment of such design tasks can then be extended to include the provisional patenting opportunities, mini-business plans, and national innovation competitions (Figure 2).

Table 3. Benefits of integrating entrepreneurial and intrapreneurial education in engineering sciences.

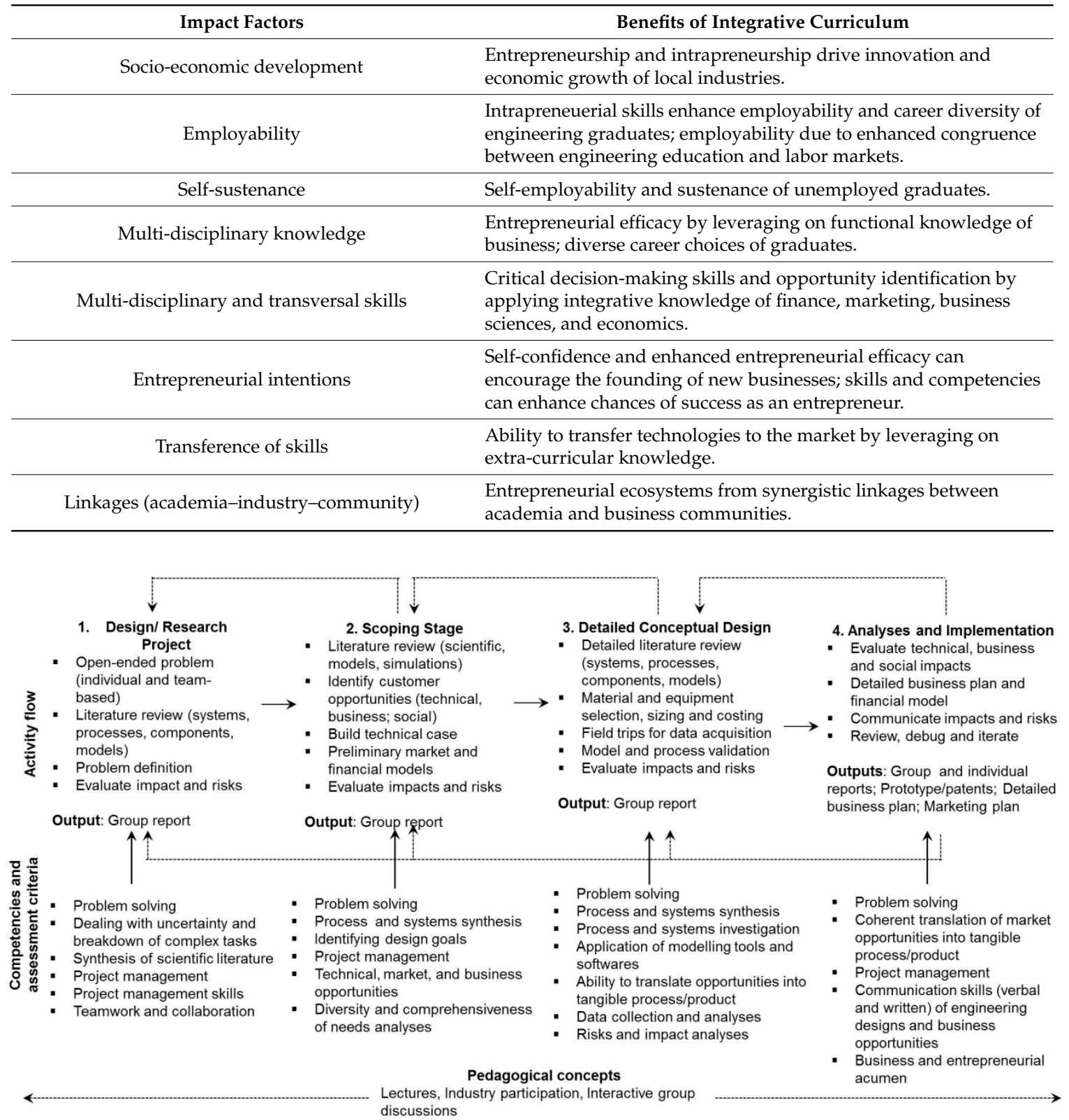

Figure 2. Implementation framework for integration into existing curricula.

As opposed to the University of Zimbabwe, which may need to introduce a new capstone design course, the proposed implementation framework for Wits seeks to link the design (CDHF) and research (ACEF) components of the current curricula to core attributes of entrepreneurship education (BDGH). In other words, the learning outcomes in the current program at Wits can further be expanded to align the current tenets of engineering practice with additional dimensions of entrepreneurship, such as the ability to identify business opportunities and to develop detailed financial, business and marketing plans. In fact, the approach to entrepreneurship education proposed in this paper can practically be considered in its systems approach and transdisciplinary nature by integrating the traditional engineering design goals, such as product design and prototyping to market analyses and innovation capabilities $[30,31,63]$. In essence, the desired creative problem-solving competencies proposed by 
Liebenberg and Mathews [63] can also be easily aligned with proposed cognitive entrepreneurial competencies (plane BDGH) such as opportunity recognition, business case and value proposition, and risk assessment [30,73-75].

\subsection{Stakeholders Interests}

The contextual literature highlighted so far clearly reinforces the need for debate towards incorporating entrepreneurship education, or some tenets of it, into the current mainstream education space. The critical success factors of the proposed integrative curriculum is predicated on a wide range of factors such as, among others, (1) enhancing universities-industry collaboration as catalysts to innovation and commercialization of technologies [29,76-79], (2) holistic macro- and micro-alignment of entrepreneurial and engineering learning outcomes and pedagogical practices [31,46,80], (3) promoting collaborative activities between entrepreneurship and non-entrepreneurship faculties [72], and (4) providing financial support through entrepreneurship networks and centers for teaching development and research in order to stimulate the interests of non-entrepreneurship faculties [72]. However, the constrained economic conditions in Zimbabwe and South Africa are very much likely to impact the potential benefits of the proposed curriculum changes.

In most institutions of higher learning, the majority of engineering faculties tend to operate within the confines of their core disciplines by focusing on generating new knowledge within narrow disciplinary and cognitive spectrums [81]. This means that the efficacy of the proposed integrative curricula is predicated on holistic problem-solving approaches within a broader and transdisciplinary social and economic context $[30,39,46,81,82]$. Thus, for the proposed integration to be successful, the implementation framework will have to further take into account the agency and interests of non-entrepreneurial academics in the curriculum review process and in the design of the requisite pedagogic practices [30-32,63,75,81,82]. In addition, for integration, the proposed implementation framework (Table 4) requires multi-stakeholder involvement in the pre- and post-curriculum construction process.

Table 4. Summary of stakeholders' involvement in pre- and post-curriculum construction process.

\begin{tabular}{|c|c|}
\hline Key Stakeholders & Interests and Involvement of Stakeholders \\
\hline Academics & $\begin{array}{l}\text { Academics' agency on many facets of curriculum (alignment of content, structure } \\
\text { and teaching and learning practices); multi-disciplinary teaching and research } \\
\text { approaches that integrate engineering and business practices, viz., teaching for and } \\
\text { through entrepreneurship. }\end{array}$ \\
\hline Alumni & $\begin{array}{l}\text { Pre- and post-curriculum construction review (alignment of content, structure, and } \\
\text { curriculum intentions) based on own experiences and diversity of career paths. }\end{array}$ \\
\hline Learners & $\begin{array}{l}\text { Active participants in curriculum construction; reflexivity based on own perceptions } \\
\text { of entrepreneurship education and desired entrepreneurial efficacy. }\end{array}$ \\
\hline Academic institutions & $\begin{array}{l}\text { Pre- and post-curriculum construction review (alignment of content, structure, } \\
\text { teaching and learning practices and resources) based on institutional baselines; } \\
\text { infrastructure and resources; alignment of proposed curriculum into the broader } \\
\text { institutional context; monitoring and evaluation of teaching and learning practices. }\end{array}$ \\
\hline Higher education qualifications authorities & $\begin{array}{l}\text { Pre- and post-curriculum construction review (content, structure, teaching and } \\
\text { learning practices, and quality control). }\end{array}$ \\
\hline State and funding institutions & $\begin{array}{l}\text { Priority areas and skills; incentives of projects with commercial potential; providing } \\
\text { incentives for high-impact research and projects; post-construction assessment and } \\
\text { evaluation of impact of proposed curriculum. }\end{array}$ \\
\hline Industry incubators & $\begin{array}{l}\text { Consultancy and advisory (curriculum content and structure); catalysts for } \\
\text { universities-industry collaborations. }\end{array}$ \\
\hline Regulatory and professional bodies & $\begin{array}{l}\text { Collaborative consultation in pre- and post-curriculum construction process } \\
\text { (alignment of content, structure, teaching and evaluations practices); accreditation, } \\
\text { monitoring and evaluation of desired competencies. }\end{array}$ \\
\hline Industry board & \multirow{2}{*}{$\begin{array}{l}\text { Collaborative consultation in curriculum construction process (alignment of content } \\
\text { and structure) based on priority entrepreneurial and intrapreneurial skills for } \\
\text { industry and society; pre- and post-construction assessment and evaluation of } \\
\text { socio-economic impact of proposed curriculum. }\end{array}$} \\
\hline Non-profit organizations & \\
\hline
\end{tabular}




\section{Conclusions}

This paper focused on the comparative evaluation of the current Metallurgy and Materials Engineering curricula at two national universities in Africa. This paper explored potential opportunities to integrate entrepreneurial and intrapreneurial education into undergraduate curricula at two universities. Comparative content analyses of the two curricula revealed a strong emphasis on disciplinary problem solving and inquiry-based learning through cornerstone and capstone research and design projects. A 3D bcc model was proposed to integrate entrepreneurial and intrapreneurial education into the existing curricula. The proposal for review of the two curricula is premised on integrating the sixth plane of the bcc model to represent the additional dimensions of graduate attributes.

Funding: This research received no external funding.

Acknowledgments: The author acknowledges valuable comments from Lynne Slonimsky, Rieta Ganas and Geoffrey S. Simate.

Conflicts of Interest: The views expressed in this paper are solely the author's based on personal knowledge of the two curricula under discussion, and do not imply any structural weaknesses in the curricula of the institutions reviewed. The author takes sole responsibility for any omissions and factual misrepresentations that may be contained in this paper.

\section{References}

1. Cornbleth, C. Curriculum in and out of context. J. Curric. Superv. 1988, 3, 85-96.

2. Knight, P.T. Complexity and curriculum: A process approach to curriculum making. Teach. High. Educ. 2001, 6, 369-381. [CrossRef]

3. Luckett, K. A proposal for epistemically diverse curriculum for South Africa in South African higher education in the 21st century. S. Afr. J. High. Educ. 2001, 15, 49-61.

4. Case, J.; Fraser, D.M.; Kumar, A.; Itika, A. The significance of context for curriculum development in engineering education: A case study across three African countries. Eur. J. Eng. Educ. 2016, 41, 279-292. [CrossRef]

5. Luckett, K.; Sutherland, L. Assessment practices that improve teaching and learning. In Improving Teaching and Learning in Higher Education; Makoni, S., Ed.; Witwatersrand University Press: Johannesburg, South Africa, 2000; pp. 98-130.

6. Barnett, R. University knowledge in an age of supercomplexity. High. Educ. 2000, 40, 409-422. [CrossRef]

7. Barnett, R. Knowing and becoming in the higher education curriculum. Stud. High. Educ. 2009, 34, 429-440. [CrossRef]

8. Andrews, J.; Higson, H. Graduate employability, 'soft' skills versus 'hard' business knowledge: A European study. High. Educ. Eur. 2008, 33, 411-422. [CrossRef]

9. Nair, C.S.; Patil, A.; Mertova, P. Re-engineering graduate skills-A case study. Eur. J. Eng. Educ. 2009, 34, 131-139. [CrossRef]

10. Case, J. Knowledge matters: Interrogating the curriculum debate in engineering using sociology of knowledge. J. Educ. 2011, 51, 1020.

11. Slonimsky, L.; Ganas, R.; University of Witwatersrand, Johannesburg, South Africa. Curriculum design and development in higher education. Private communication, 2017.

12. Cameron, I.T.; Lewin, D.R. Curricular and pedagogical challenges for enhanced graduate attributes in CAPE. Comput. Chem. Eng. 2009, 33, 1781-1792. [CrossRef]

13. Silva, P.; Yarlagadda, P.K.V.D. Complete and competent engineers: A coaching model to developing holistic graduates. Proceedia Soc. Behav. Sci. 2014, 116, 1367-1372. [CrossRef]

14. Male, S.; Bush, M.B.; Chapman, E.S. Perceptions of competency deficiencies in engineering graduates. Australas. J. Eng. Educ. 2010, 16, 55-67. [CrossRef]

15. Latuca, L.R.; Knight, D.B.; Ro, H.K.; Novoselich, B.J. Supporting the development of engineers' interdisciplinary competence. J. Eng. Educ. 2017, 106, 71-97. [CrossRef]

16. Schumpeter, J.A. Business Cycles: A Theoretical, Historical, and Statistical Analysis of the Capitalist Process; McGraw-Hill: New York, NY, USA, 1939. 
17. Schumpeter, J.A. Capitalism, Socialism and Democracy; Harper and Brothers: New York, NY, USA, 1942.

18. Porter, M.E. How competitive forces shape strategy. Harv. Bus. Rev. 1979, 57, 137-145.

19. Porter, M.E. The Competitive Advantage of Nations; Free Press: New York, NY, USA, 1990.

20. Wennekers, S.; Thurik, R. Linking entrepreneurship and economic growth. Small Bus. Econ. 1999, 13, 27-55. [CrossRef]

21. Dejardin, M. Entrepreneurship and Economic Growth: An Obvious Conjunction? Institute of Development Strategies Indiana University: Bloomington, IN, USA, 2000. Available online: https:/ / www.researchgate.net/ profile/Marcus_Dejardin/publication/23742141_Entrepreneurship_and_Economic_Growth_An_Obvious_ Conjunction/links/53f613510cf2fceacc6ffe2d.pdf (accessed on 5 July 2017).

22. Fields, G.S.; Pfeffermann, G. Reducing Poverty: The Overall Framework. In Pathways Out of Poverty: Private Firms and Economic Mobility in Developing Countries; Fields, G.S., Pfeffermann, G., Eds.; Kluwer Academic Publishers: Boston, MA, USA, 2003; pp. 1-11.

23. Baumol, W.J. Education for Innovation: Entrepreneurial breakthroughs versus corporate incremental improvements. In Innovation Policy and the Economy 5; Jaffe, A.B., Lerner, J., Stern, S., Eds.; The MIT Press: Cambridge, MA, USA, 2005; ISBN 0262101092. Available online: http:/ / www.nber.org/chapters/c10806.pdf (accessed on 19 June 2019).

24. Wong, P.K.; Ho, Y.P.; Autio, E. Entrepreneurship, innovation and economic growth: Evidence from GEM data. Small Bus. Econ. 2005, 24, 335-350. [CrossRef]

25. Assink, M. Inhibitors of disruptive innovation capability: A conceptual model. Eur. J. Innov. Manag. 2006, 9 , 215-233. [CrossRef]

26. Nichols, S.P.; Armstrong, N.E. Engineering entrepreneurship: Does entrepreneurship have a role in engineering education? IEEE Antennas Propag. Mag. 2003, 45, 134-138. Available online: http: / /ieeexplore. ieee.org/stamp/stamp.jsp?arnumber=1189659 (accessed on 19 June 2017). [CrossRef]

27. Williams, D.K. The four essential traits of intraprenuers, 2013. Forbes Magazine. Available online: https: / /www.forbes.com/sites/davidkwilliams/2013/10/30/the-4-essential-traits-of-intrapreneurs / \#3d4c4a951da2 (accessed on 19 June 2017).

28. Kuratko, D.F. The emergence of entrepreneurship education: Development, trends, and challenges. Entrep. Theory Pract. 2005, 29, 577-598. [CrossRef]

29. Laukkanen, M.I. Exploring alternative approaches in high level entrepreneurship education: Creating micro-mechanisms for endogenous regional growth. Entrep. Reg. Dev. 2000, 12, 25-47. [CrossRef]

30. Täks, M.; Tynjälä, P.; Toding, M.; Kukemelk, H.; Venesaar, U. Engineering students' experiences in studying entrepreneurship. J. Eng. Educ. 2014, 103, 573-598. [CrossRef]

31. Oswald-Beiler, M.R. Integrating innovation and entrepreneurship principles into civil engineering curriculum. J. Prof. Issues Eng. Educ. Pract. 2015, 141, 1-8. [CrossRef]

32. Bernstein, B. Vertical and horizontal discourses: An essay. Br. J. Sociol. Educ. 1999, 20, 157-173. [CrossRef]

33. Atrens, A.; Truss, R.W.; Dahle, A.; Schaffer, G.B.; ST John, D.H.; Caceres, C.; Gates, J.D. Graduate attributes in relation to curriculum design and delivery in a Bachelor of Materials Engineering Program. Int. J. Eng. Educ. 2004, 20, 834-848.

34. Maton, K. Knowledge-Knower Structures in Intellectual and Educational Fields. In Language, Knowledge and Pedagogy: Functional Linguistic and Sociological Perspectives; Christie, F., Martin, J.R., Eds.; Continuum: London, UK, 2005; pp. 87-108.

35. Hassan, O.A.B. Learning theories and assessment methodologies: An engineering educational perspective. Eur. J. Eng. Educ. 2011, 36, 327-339. [CrossRef]

36. Engineering Council of South Africa. Whole Qualification Standard for Bachelor of Science in Engineering $(\mathrm{BSc}(\mathrm{Eng})) /$ Bachelors of Engineering (BEng). 2004. Available online: https: / / www.ecsa.co.za/RegisterDocuments / FileNames / BSc(Eng))\%20\%20Bachelors\%20Of\%20Engineering\% 20(BEng)\%20Programmes.pdf (accessed on 9 July 2017).

37. Spinks, N.; Silburn, N.; Birchall, D. Educating Engineers for the 21st Century: The Industry View; Henley Management College for Roya Academy of Engineering: Oxfordshire, UK, 2006.

38. Johnson, A.; King, R.; Bradley, A.; O'Kane, M. Engineers for the Future: Addressing the Supply and Quality of Australian Engineering Graduates for the 21st Century; Australian Council of Engineering Deans: Epping, Australia, 2008. 
39. Dym, C.L.; Agogino, A.M.; Eris, O.; Frey, D.D.; Leifer, L.J. Engineering design thinking, teaching and learning. J. Eng. Educ. 2005, 94, 103-120. [CrossRef]

40. Sunthonkanokpong, W. Future global visions of engineering education. Proc. Eng. 2011, 8, 160-164. [CrossRef]

41. Dym, C.L. Engineering Design: A Synthesis of Views; Cambridge University Press: New York, NY, USA, 1994.

42. Dym, C.L. Design, systems, and engineering education. Int. J. Eng. Educ. 2004, 20, 305-312.

43. Sterman, J.D. Systems dynamics modelling: Tools for learning in a complex world. Calif. Manag. Rev. 2001, 43, 8-25. [CrossRef]

44. Bridgstock, R. The graduate attributes we've overlooked: Enhancing graduate employability through career management skills. High. Educ. Res. Dev. 2009, 28, 31-44. [CrossRef]

45. Katz, R. Integrating analysis and design in mechanical engineering education. Proceedia CIRP 2015, 36, 23-28. [CrossRef]

46. Mäkimurto-Koivumaa, S.; Belt, P. About, for, in or through entrepreneurship in engineering education. Eur. J. Eng. Educ. 2016, 41, 512-529. [CrossRef]

47. Rust, V.D. Method and methodology in Comparative Education. Comp. Educa. Rev. 2003, 47, 3-7. [CrossRef]

48. Benavot, A. Strengthening the Comparative Dimension in Comparative Education (Research). CICE Seminar, Hiroshima University. 2012. Available online: https:/ /home.hiroshima-u.ac.jp/cice/wp-content/uploads / Seminar/HandOut/146_handout.pdf (accessed on 13 August 2018).

49. National Research Council; Committee for a Review of the Evaluation Data on the Effectiveness of NSF-Supported and Commercially Generated Mathematics Curriculum Materials; Mathematical Sciences Education Board; Centre of Education; Division of Behavioural and Social Sciences and Education. On Evaluating Curricular Effectiveness: Judging the Quality of K-12 Mathematics Evaluations; Confrey, J., Stohl, V., Eds.; National Academies Press: Washington, DC, USA, 2004; pp. 65-95.

50. Government of Zimbabwe. Zimbabwe Agenda for Sustainable Socio-Economic Transformation (ZIM-ASSET)-Towards an Empowered Society and a Growing Economy. 2013. Available online: https: / / www.dpcorp.co.zw/assets / zim-asset.pdf (accessed on 9 November 2018).

51. Baxter, R. Beneficiation: Mining industry viewpoint. In Proceedings of the LBMA Precious Metals Conference 2005, Johannesburg, South Africa, 13-15 November 2005; pp. 25-28.

52. Department of Trade and Industry. Industrial Policy Action Plan: Economic Sectors and Employment Cluster; IPAP 2013/14-2015/16; Department of Trade and Industry: Pretoria, South Africa, 2013.

53. Matinde, E.; Makoni, E. Value addition and Beneficiation: Developing and capabilities driven beneficiation framework for the iron and steel sector in Zimbabwe. In Mineral Processing: Technologies, Challenges and Perspectives; Padmanabham, G., Ed.; Daya Publishing House: New Delhi, India, 2017; pp. 21-65.

54. Moses, C.; Sithole, M.; Labadarios, D.; Blankley, W. South African Innovation Survey: Main Results 2008; Human Sciences Research Council: Pretoria, South Africa, 2011. Available online: file:/ / /C:/Users/a0042750/ Downloads / 6996.pdf (accessed on 20 July 2017).

55. Davies, M.; Devlin, M. Interdisciplinarity in Higher Education: Implications for Teaching and Learning; Centre for the Study of Higher Education: Parkville, VIC, Australia, 2007.

56. Woods, C. Researching and developing interdisciplinary teaching: Towards a conceptual framework for classroom communication. High. Educ. 2007, 54, 853-866. [CrossRef]

57. Walter, H. Curriculum for excellence and interdisciplinary learning. Scott. Educ. Rev. 2013, 45, 82-93.

58. Brew, A. Teaching and research: New relationships and their implications for inquiry-based teaching and learning in higher education. High. Educ. Res. Dev. 2003, 22, 3-8. [CrossRef]

59. Healey, M. Linking Research and Teaching: Exploring Disciplinary Spaces and the Role of Inquiry-Based, Learning. In Reshaping the University: New Relationships between Research, Scholarship and Teaching; Barnett, R., Ed.; McGraw Hill/Open University Press: London, UK, 2005; pp. 67-78.

60. Healey, M. Linking research and teaching to benefit student learning. J. Geogr. High. Educ. 2005, $29,183-201$. [CrossRef]

61. Grimson, J. Re-engineering the curriculum for the 21st century. Eur. J. Eng. Educ. 2002, 27, 31-37. [CrossRef]

62. Kolb, D.A. Experiential Learning: Experiences as the Source of Learning and Development; Prentice Hall: Englewood Cliffs, NJ, USA, 1984; pp. 25-38.

63. Liebenberg, L.; Mathews, E.H. Integrating innovation skills in an introductory engineering design-build course. Int. J. Technol. Des. Educ. 2012, 22, 93-113. [CrossRef] 
64. Evans, D.L.; McNeill, B.W.; Beakley, G.C. Design engineering education: Past views of future directions. J. Eng. Educ. 1990, 79, 517-522.

65. Beder, S. Beyond technicalities: Expanding engineering thinking. J. Prof. Issues Eng. Educ. Pract. 1999, 125, 12-18. [CrossRef]

66. Savage, R.N. The role of design in materials science and engineering. Int. J. Eng. Educ. 2006, 22, 917-924.

67. Chung, Y.W. Introduction to Materials Science and Engineering; CRC Press: Boca Raton, FL, USA, 2006; pp. 14-16.

68. Callister, W.D., Jr.; Rethwisch, D.G. Fundamentals of Materials Science and Engineering: An integrated Approach, 3rd ed.; John Wiley and Sons: Hoboken, NJ, USA, 2008; pp. 37-45.

69. DeFillippi, R.J.; Arthur, M.B. The boundary less career-a competency based perspective. J. Organ. Behav. 1994, 15, 307-324. [CrossRef]

70. Kriewall, T.J.; Mekemson, K. Instilling the entrepreneurial mindset into engineering undergraduates. J. Eng. Entrep. 2010, 1, 5-19.

71. Odora, R.J. Integrating product design and entrepreneurship education: A stimulant for enterprising design and engineering students in South Africa. Proc. Technol. 2015, 20, 276-283. [CrossRef]

72. Standish-Kuon, T.; Rice, M.P. Introducing engineering and science students to entrepreneurship: Models and influential factors at six American Universities. J. Eng. Educ. 2002, 91, 33-39. [CrossRef]

73. Baron, R.A. Cognitive mechanisms in entrepreneurship: Why and when entrepreneurs think differently than other people. J. Bus. Ventur. 1998, 13, 275-294. [CrossRef]

74. Morris, M.H.; Webb, J.W.; Fu, J.; Singhal, S. A competency-based perspective on entrepreneurship education: Conceptual and empirical insights. J. Small Bus. Manag. 2013, 51, 352-369. [CrossRef]

75. Sirelkhatim, F.; Gangi, Y. Entrepreneurship education: A systematic literature review of curriculula contents and teaching methods. Cogent Bus. Manag. 2015, 2, 1-11. [CrossRef]

76. Iyuke, P.O.; Cross, M.; Iyuke, S.E.; Potgieter, H.J. The role of university in education and training in the field of nanotechnology: The case of the University of Witwatersrand. Trans IChemE 2007, 2, 56-67.

77. Perkmann, M.; Walsh, K. University industry relationships and open innovation: Towards a research agenda. Int. J. Manag. Rev. 2007, 9, 259-280. [CrossRef]

78. Klofsten, M.; Jones-Evans, D. Simulation of technology-based small firms-A Case study of university-industry cooperation. Technovation 1996, 16, 187-193. [CrossRef]

79. Subotzky, G. Alternatives to the entrepreneurial university: New modes of knowledge production in community service programs. Hig. Educ. 1999, 38, 401-440. [CrossRef]

80. Hynes, B. Entrepreneurship education and training-Introducing entrepreneurship into non-business disciplines. J. Eur. Ind. Train. 1996, 20, 10-17. [CrossRef]

81. National Academies Press. Facilitating Interdisciplinary Research; The National Academies Press: Washington, DC, USA, 2005; pp. 26-40.

82. Gibbons, M.; Limoges, C.; Nowotny, H.; Schwartzman, S.; Scott, P.; Trow, M. The New Knowledge Production: The Dynamics of Science and Research in Contemporary Societies; SAGE Publications: London, UK, 1994; pp. 1-16. 